Fetal Diagnosis
and Therapy
Fetal Diagn Ther 2008;23:204-210

DOI: $10.1159 / 000116742$
Received: February 1, 2005

Accepted after revision: December 15, 2006

Published online: February 20, 2008

\title{
Analysis of Factors Influencing the Ultrasonic Fetal Weight Estimation
}

\author{
Ivo Markus Heer ${ }^{a}$ Carolin Kümper ${ }^{a}$ Nadin Vögtle ${ }^{b}$ Susanne Müller-Egloff ${ }^{c}$ \\ Martin Dugas $^{d}$ Alexander Strauss $^{\mathrm{a}}$ \\ ${ }^{a}$ Department of Obstetrics and Gynecology, University Hospital Schleswig-Holstein, University Kiel, Kiel, \\ ${ }^{b}$ Department of Obstetrics and Gynecology, Krankenhaus Dritter Orden, München-Nymphenburg, \\ 'Department of Obstetrics and Gynecology-Grosshadern, University Hospital, University of Munich, Munich, and \\ ${ }^{\mathrm{d} D e p a r t m e n t}$ of Medical Informatics, Biometrics, University of Münster, Münster, Germany
}

\section{Key Words}

Fetal weight estimation $\cdot$ Sonography $\cdot$ Impact

\begin{abstract}
Objective: The aim of our study was the evaluation of sonographic fetal weight estimation taking into consideration 9 of the most important factors of influence on the precision of the estimation. Methods: We analyzed 820 singleton pregnancies from 22 to 42 weeks of gestational age. We evaluated 9 different factors that potentially influence the precision of sonographic weight estimation (time interval between estimation and delivery, experts vs. less experienced investigator, fetal gender, gestational age, fetal weight, maternal BMI, amniotic fluid index, presentation of the fetus, location of the placenta). Finally, we compared the results of the fetal weight estimation of the fetuses with poor scanning conditions to those presenting good scanning conditions. Results: Of the 9 evaluated factors that may influence accuracy of fetal weight estimation, only a short interval between sonographic weight estimation and delivery (0-7 vs. 8-14 days) had a statistically significant impact. Conclusion: Of all known factors of influence, only a time interval of more than 7 days between estimation and delivery had a negative impact on the estimation.

Copyright $\odot 2008$ S. Karger AG, Basel
\end{abstract}

\section{Introduction}

Monitoring fetal growth by sonographic weight estimation is well established during antenatal care and of importance due to the rising incidence of high-risk and iatrogenic multiple pregnancies [1]. The introduction of PACS (picture archiving and communication system) with automatically generated weight estimation after biometry supplies the sonographer with a powerful tool that gives him or her a false sense of accuracy in a 'measured' current fetal weight. This apparent exactness led us to the question which factors may flaw precision. The methods and formulas to attain reliable weight estimations are well known [2-4]. Although there exist good data of fetal weight estimation by ultrasound, there is still one important question to be answered: What factors of influence have to be considered when assessing the precision of the fetal weight estimation? The literature where different impact factors are analyzed is contradictory (see Discussion) and motivated this work. To our knowledge, this is the first study to analyze 9 important factors that may influence the precision of the sonographic fetal weight estimation in a study group of singleton pregnancies.

\section{KARGER}

Fax +4161306 1234 E-Mail karger@karger.ch www.karger.com
(C) 2008 S. Karger AG, Basel

$1015-3837 / 08 / 0233-0204 \$ 24.50 / 0$

Accessible online at:

www.karger.com/fdt
Dr. Ivo Markus Heer

Klinik für Frauenheilkunde und Geburtshilfe

Universitätsklinikum Schleswig-Holstein

Michaelisstrasse 16, DE-24 105 Kiel (Germany)

Tel. +49 431597 2100, Fax +49 431597 2145, E-Mail iheer@email.uni-kiel.de 


\section{Methods}

Between December 2000 and March 2003, we studied 820 singleton pregnancies of mothers who attended our antenatal care unit in the Clinic for Obstetrics and Gynecology of Munich University Hospital Grosshadern. We included only singleton pregnancies that were delivered at our institution within 14 days of the last sonographic scan and with a birth weight $>500$ g. We excluded multiple pregnancies because of their different intrauterine growth pattern [5]. Stillborn fetuses were also excluded. In this study we had no fetal malformations that presumably would have affected the preciseness of the biometry (i.e. gastroschisis, omphalocele, hydrocephalus). The 820 pregnancies were divided into subgroups according to gestational age (weeks 22-24, 25-26, 27-28, 29-30, 31-32, 33-34, 35, 36, 37, 38, 39, 40, 41) and subgroups according to birth weight $(500-1,000,1,001-1,500,1,501-$ $2,000,2,001-2,500,2,501-3,000,3,001-3,500,3,501-4,000,4,001-$ $4,500,>4,501 \mathrm{~g})$. We evaluated biparietal diameter (BPD), femur length (FL), circumference of the fetal head (HC) and abdominal circumference (AC) [6].

All calculations were carried out in absolute numbers (grams) and were transformed into the corresponding percentiles, to provide better comparability between the different subgroups of birth weight [7].

To obtain fetal weight estimations we relied on 6 widespread formulas: Hadlock I [8], Hadlock II [9], Hadlock III [9], Warsof [10], Merz [11] and Shepard [12]. With every formula we calculated the percentage of fetuses, which were in a $\pm 10 \%$ range of the actual birth weight and the mean deviation percentage from the actual birth weight in the stratified groups of weight and week of delivery.

As study goal we evaluated 9 important factors that influence the accuracy of prenatal weight estimation. All 9 influence factors were dichotomized and compared in pairs to calculate a possible significant difference in the accuracy of fetal weight estimation between the pairs.

\begin{tabular}{|c|c|c|}
\hline $\begin{array}{l}\text { Fac- } \\
\text { tor }\end{array}$ & Influence factor & Definition \\
\hline 1 & $\begin{array}{l}\text { Time interval between } \\
\text { estimation and delivery }\end{array}$ & $0-7$ vs. $8-14$ days \\
\hline 2 & $\begin{array}{l}\text { Expert vs. less } \\
\text { experienced investigator }\end{array}$ & $\begin{array}{l}\text { Expert: highly skilled ultrasonog- } \\
\text { rapher with proofed qualification } \\
\text { vs. less experienced investigator: } \\
\text { proofed skills on basic ultrasound }\end{array}$ \\
\hline 3 & Fetal gender & Female vs. male \\
\hline 4 & Gestational age & $<30$ vs. $\geq 30$ weeks \\
\hline 5 & Fetal weight & $<2,000$ vs. $\geq 2,001 \mathrm{~g}$ \\
\hline 6 & Maternal BMI & $<25$ vs. $\geq 25$ \\
\hline 7 & $\begin{array}{l}\text { Amniotic Fluid } \\
\text { Index (13) }\end{array}$ & $\begin{array}{l}\text { Lower than normal AFI, oligo- } \\
\text { or ahydramnion vs. } \geq \text { normal } \\
\text { amount of amniotic fluid }\end{array}$ \\
\hline 8 & Presentation of fetus & Cephalic vs. other presentations \\
\hline 9 & Location of the placenta & $\begin{array}{l}\text { Anterior uterine wall vs. other } \\
\text { location }\end{array}$ \\
\hline
\end{tabular}

Fetal Weight Estimation
Factors 1-5 are independent from the scanning conditions. Factors 6-9 may affect the visibility and therefore potentially worsen the accuracy of the sonographic weight estimation because the landmarks where the calipers have to be set may not precisely visible.

To analyze the impact of visibility on the preciseness of fetal weight estimation, we pooled mothers with very poor imaging conditions caused by maternal obesity combined with little amnion fluid (maternal BMI >25.1 and AFI lower than normal, oligo- or ahydramnion). These were compared with pregnancies presenting better imaging conditions (maternal BMI $<25$ and normal amniotic fluid).

All scans were performed using curved array transducers with 4 or $5 \mathrm{MHz}$ from the Acuson XP 128 or Acuson Seqoia $512^{\mathrm{TM}}$ platform. Data were electronically archived with a PACS (PIA Fetal Database, ViewPoint, GE Medical Systems, Wessling, Germany).

Statistical analysis was performed using the Mann-Whitney U test. The absolute and the percentage standard deviation were calculated with Microsoft Office Excel 2000.

\section{Results}

During the study period we analyzed 820 pregnancies between 23 and 42 weeks of gestational age (median $37^{+3}$ ), fetal birth weight ranging from 530 to 5,020 g (median $3,016 \mathrm{~g}$ ) and maternal age ranged from 18 to 47 years (median 33 years). Figures 1 and 2 demonstrate the number of fetuses in the different subgroups according to gestational age and actual birth weight.

First we compared the accuracy of the 6 formulas. Estimations within a $\pm 10 \%$ range of the actual birth weight varied from $54.6 \%$ (Hadlock I) to $63.4 \%$ (Hadlock II). The different size of the subgroups results from missing single parameters of the sonographic biometrical investigation (table 1).

Though there are differences in the $\pm 10 \%$ range of the sonographic fetal weight estimation (54.6-62.3\%, table 1), none of the formulas provided us with statistically superior results in general or in one of the subgroups.

The mean \% deviation from the actual birth weight is shown in figure 2 and varied between $-6.21 \pm 11.09 \%$ (Hadlock I) and $+4.03 \pm 11.43 \%$ (Merz). The smallest \% deviation to the actual birth weight was provided by Shepard's formula: $+0.22 \pm 12.05$.

In order to select one of the 6 formulas for further evaluation of impact factors on the accuracy of the sonographic fetal weight estimation, we proved the comparability of the 6 subcollectives to exclude any formula bias. The referring results are shown in table 2 . 


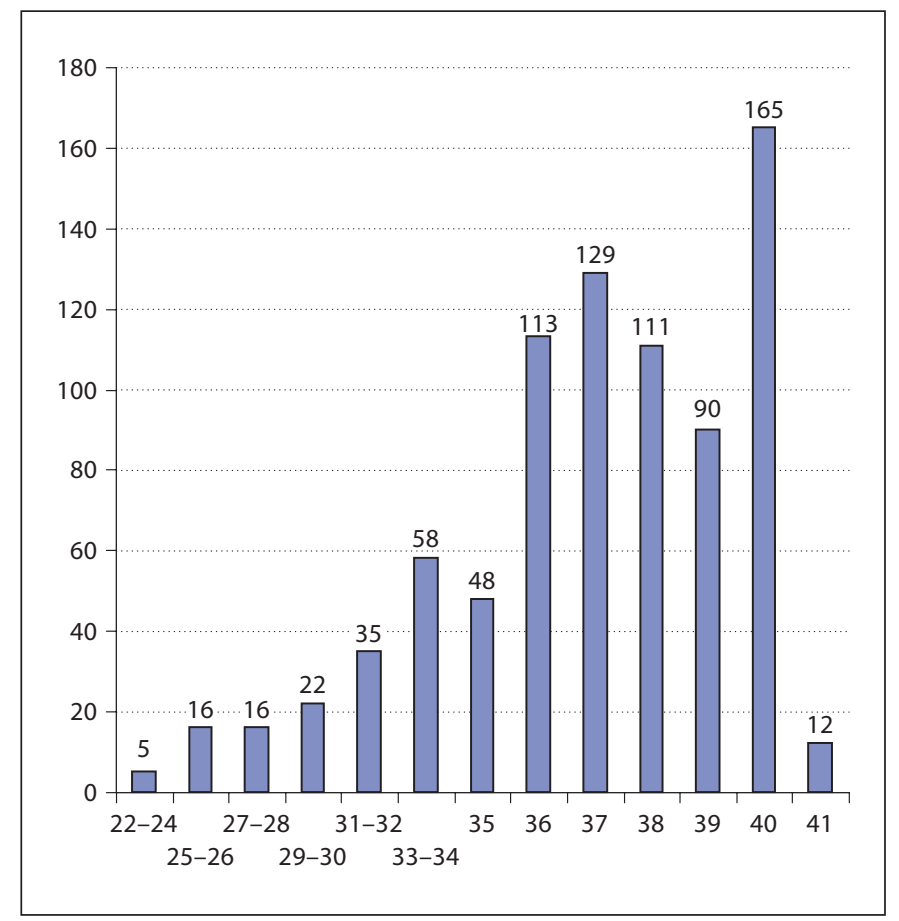

Fig. 1. Number of fetuses in the different subgroups of gestational age.

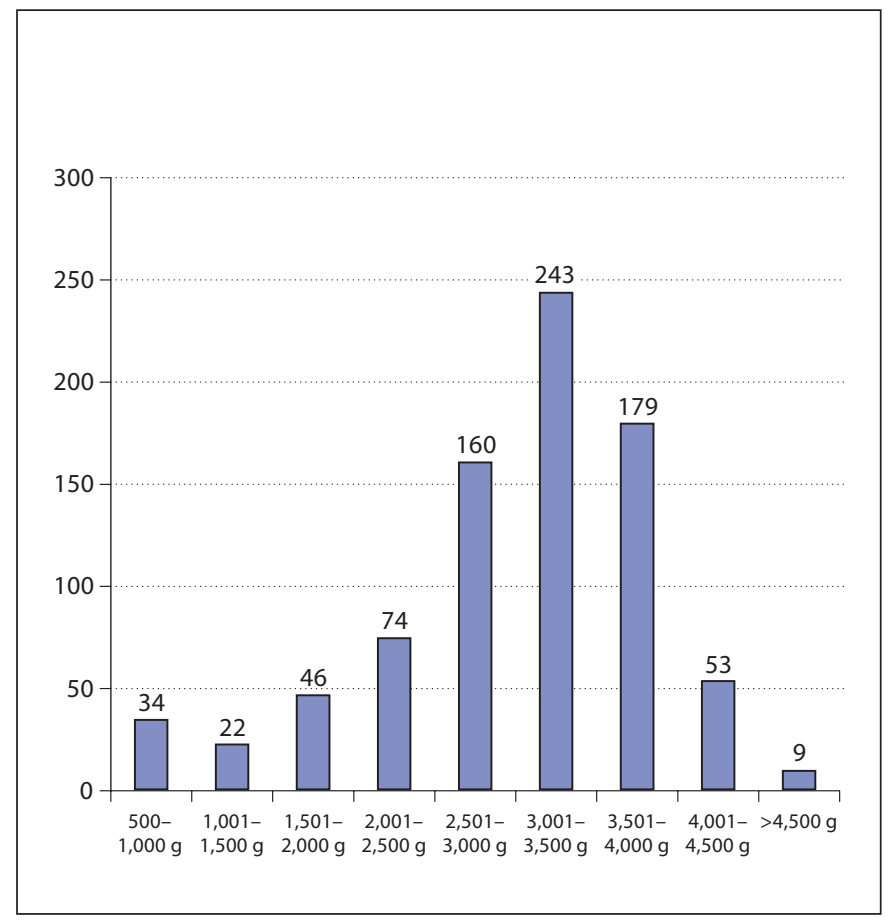

Fig. 2. Number of fetuses in the different subgroups of birth weight.

Table 1. Formulas used for fetal weight estimation and percentages of estimation within $\pm 10 \%$ range of actual weight

\begin{tabular}{|c|c|c|c|}
\hline & Formula & $\mathrm{n}$ & $\begin{array}{l}\text { Estimation within } \pm 10 \% \\
\text { range of actual weight }\end{array}$ \\
\hline Hadlock I & $\begin{array}{l}\log _{10}(\mathrm{EFW})=1.304+0.05281(\mathrm{AC})+0.1938(\mathrm{FL}) \\
-0.004(\mathrm{AC} \times \mathrm{FL})(\mathrm{cm}, \mathrm{g})\end{array}$ & 769 & $54.6 \%$ \\
\hline Hadlock II & $\begin{array}{l}\log _{10}(\mathrm{EFW})=1.335-0.0034(\mathrm{AC} \times \mathrm{FL})+0.0316(\mathrm{BPD})+0.0457(\mathrm{AC}) \\
+0.1623(\mathrm{FL})(\mathrm{cm}, \mathrm{g})\end{array}$ & 767 & $63.4 \%$ \\
\hline Hadlock III & $\begin{array}{l}\log _{10}(\mathrm{EFW})=1.3596-0.00386(\mathrm{AC} \times \mathrm{FL})+0.0064(\mathrm{HC})+0.00061 \\
(\mathrm{BPD} \times \mathrm{AC})+0.0424(\mathrm{AC})+0.174(\mathrm{FL})(\mathrm{cm}, \mathrm{g})\end{array}$ & 671 & $61.4 \%$ \\
\hline Warsof & $\begin{array}{l}\log _{10}(\mathrm{EFW})=-1.599+0.144(\mathrm{BPD})+0.032(\mathrm{AC}) \\
-0.111\left(\mathrm{BPD}^{2} \times \mathrm{AC}\right) / 1,000(\mathrm{~cm}, \mathrm{~kg})\end{array}$ & 818 & $58.7 \%$ \\
\hline Merz & $\begin{array}{l}\mathrm{EFW}=-3200,40479+157,07186(\mathrm{AC})+15,90391(\mathrm{BPD})^{2}(\mathrm{~cm}, \mathrm{~g}) \\
(\text { valid from 1,000 g, BPD 7.0-10.5 cm, AC 21.8-36.5 cm) }\end{array}$ & 719 & $62.3 \%$ \\
\hline Shepard & $\begin{array}{l}\log _{10}(\mathrm{EFW})=-1.7492+0.166(\mathrm{BPD})+0.046(\mathrm{AC}) \\
-2.646(\mathrm{AC} \times \mathrm{BPD}) / 1,000(\mathrm{~cm}, \mathrm{~kg})\end{array}$ & 818 & $60.8 \%$ \\
\hline
\end{tabular}

$\mathrm{EFW}=$ Estimated fetal weight. 
Table 2. Differences in the subgroups of the different formulas

\begin{tabular}{|c|c|c|c|c|c|c|c|c|c|c|}
\hline Formula & $\mathrm{n}$ & $\begin{array}{l}\text { Median } \\
\text { pregnancy } \\
\text { week }\end{array}$ & $\begin{array}{l}\text { Median } \\
\text { birth } \\
\text { weight, g }\end{array}$ & $\begin{array}{l}\text { Median days } \\
\text { between estima- } \\
\text { tion and delivery }\end{array}$ & $\begin{array}{l}\% \text { of expert } \\
\text { sono- } \\
\text { graphers }\end{array}$ & $\begin{array}{l}\% \text { of } \\
\text { female } \\
\text { fetuses }\end{array}$ & $\begin{array}{l}\text { Median } \\
\text { maternal } \\
\text { BMI }\end{array}$ & $\begin{array}{l}\% \text { AFI } \\
\geq 90\end{array}$ & $\begin{array}{l}\% \text { cephalic } \\
\text { presenta- } \\
\text { tion }\end{array}$ & $\begin{array}{l}\% \text { placenta } \\
\text { abdominal } \\
\text { wall }\end{array}$ \\
\hline Hadlock I & 769 & $37^{+2}$ & 2,998 & 5.82 & 56.18 & 50.07 & 24.24 & 76.59 & 87.26 & 31.21 \\
\hline Hadlock II & 767 & $37^{+2}$ & 2,996 & 5.82 & 54.50 & 50.07 & 24.26 & 76.66 & 87.09 & 31.03 \\
\hline Hadlock III & 671 & $37^{+1}$ & 2,975 & 5.76 & 56.18 & 50.22 & 24.23 & 76.30 & 86.14 & 31.59 \\
\hline Warsof & 818 & $37^{+2}$ & 3,015 & 5.75 & 54.77 & 47.31 & 24.25 & 76.89 & 87.41 & 31.05 \\
\hline Merz & 719 & $37^{+5}$ & 3,049 & 6.1 & 54.46 & 50.15 & 24.29 & 76.22 & 89.43 & 31.15 \\
\hline Shepard & 818 & $37^{+3}$ & 3,015 & 5.75 & 54.77 & 49.61 & 24.25 & 76.89 & 87.41 & 31.05 \\
\hline
\end{tabular}

Table 3. Factors of influence on the precision of the estimation

\begin{tabular}{|c|c|c|c|c|}
\hline Influence factor & Dichotomy & $\mathrm{n}$ & $\begin{array}{l}\text { Median percentage error } \\
\text { signed percentage error }\end{array}$ & $\begin{array}{l}\text { Significant difference } \\
(\mathrm{p}<0.05)\end{array}$ \\
\hline $\begin{array}{l}\text { Time between estimation and } \\
\text { delivery }(\mathrm{n}=767)\end{array}$ & $\begin{array}{l}0-7 \text { days } \\
8-14 \text { days }\end{array}$ & $\begin{array}{l}477 \\
290\end{array}$ & $\begin{array}{c}8.52 \pm 9.82 \\
10.37 \pm 10.50\end{array}$ & Yes: $\mathrm{p}<0.001$ \\
\hline $\begin{array}{l}\text { Expert vs. basic experienced } \\
\text { investigator }(n=752)\end{array}$ & $\begin{array}{l}\text { Expert } \\
\text { Basic experienced }\end{array}$ & $\begin{array}{l}371 \\
381\end{array}$ & $\begin{array}{l}8.93 \pm 10.22 \\
9.51 \pm 11.26\end{array}$ & No: $p=0.334$ \\
\hline Fetal gender $(n=767)$ & $\begin{array}{l}\text { Male } \\
\text { Female }\end{array}$ & $\begin{array}{l}382 \\
385\end{array}$ & $\begin{array}{l}9.42 \pm 10.66 \\
9.01 \pm 10.76\end{array}$ & No: $p=0.302$ \\
\hline Gestational age $(n=761)$ & $\begin{array}{l}<30 \text { weeks } \\
\geq 30 \text { weeks }\end{array}$ & $\begin{array}{r}48 \\
713\end{array}$ & $\begin{array}{l}9.84 \pm 11.47 \\
9.16 \pm 10.66\end{array}$ & No: $p=0.302$ \\
\hline Fetal weight $(\mathrm{n}=767)$ & $\begin{array}{l}<2,000 \mathrm{~g} \\
\geq 2,000 \mathrm{~g}\end{array}$ & $\begin{array}{r}98 \\
669 \\
\end{array}$ & $\begin{array}{r}10.12 \pm 12.28 \\
9.09 \pm 10.46\end{array}$ & No: $p=0.227$ \\
\hline Maternal BMI $(\mathrm{n}=767)$ & $\begin{array}{l}\mathrm{BMI}<25 \\
\mathrm{BMI} \geq 25\end{array}$ & $\begin{array}{l}522 \\
245\end{array}$ & $\begin{array}{l}9.32 \pm 10.74 \\
8.87 \pm 10.38\end{array}$ & No: $p=0.528$ \\
\hline Amniotic Fluid Index $(\mathrm{n}=756)$ & $\begin{array}{l}\text { Normal } \\
\text { Oligohydramnion }\end{array}$ & $\begin{array}{l}590 \\
166\end{array}$ & $\begin{array}{l}8.96 \pm 10.49 \\
9.97 \pm 11.33\end{array}$ & No: $p=0.093$ \\
\hline Fetal presentation $(\mathrm{n}=754)$ & $\begin{array}{l}\text { Cephalic } \\
\text { Other }\end{array}$ & $\begin{array}{l}598 \\
156\end{array}$ & $\begin{array}{l}9.01 \pm 10.66 \\
9.98 \pm 10.73\end{array}$ & No: $p=0.145$ \\
\hline Placenta location $(\mathrm{n}=618)$ & $\begin{array}{l}\text { Other } \\
\text { Abdominal wall }\end{array}$ & $\begin{array}{l}412 \\
206\end{array}$ & $\begin{array}{l}9.41 \pm 11.07 \\
9.01 \pm 10.16\end{array}$ & No: $p=0.393$ \\
\hline
\end{tabular}

The analysis of impact of factors on the accuracy of sonographic fetal weight estimation was carried out with Hadlock II, thus including 767 fetuses and the highest percentage of estimations within the $\pm 10 \%$ range of the actual weight (table 1). Only the time between estimation and delivery had a significant impact on the accuracy of the fetal weight estimation (table 3). Beside these results the impact of sonographic visibility on the precision of the fetal weight estimation was analyzed.
We compared scans with good image quality (BMI $<25$, $\varnothing 21.48$, and AFI normal (AFI >90); $\mathrm{n}=401$ ) with scans limited by poor visibility (BMI $>25.1, \varnothing 30.91$, and AFI with lower than normal, oligo- or ahydramnion (AFI $<90) ; \mathrm{n}=47$ ). The difference of the mean percentage error between both groups was negligible (good visibility: 9.0\%, poor visibility: $9.05 \%)$. There was no difference in the accuracy of fetal weight estimation between both groups. 


\section{Discussion}

Sonographic weight estimation is an important method in fetal monitoring. In the last 25 years, numerous formulas for intrauterine estimation of fetal weight have been published. All of them are based on defined sonographic parameters such as biparietal and frontooccipital diameter, head circumference, abdominal circumference and femur length. A wide variety of other diameters, circumferences and (with the advent of the 3D sonography) volumes have been evaluated in the hope of improving the predictive value of established calculations. Most of these new formulas have yet not been clinically established.

Analyzing different formulas for weight estimation (table 2) we studied the impact of 9 key factors that could potentially influence the accuracy of the fetal weight estimation. Hadlock II, as this formula had proven the highest accuracy in our study group, was mainly used.

Only the time interval between weight estimation and delivery had a statistically significant impact on the accuracy of the study results. Of 63 studies published on factors that may influence the sonographic accuracy, 8 provided no data about the time interval between sonographic estimation and delivery. Of the remaining 55 studies, only 9 reported results of the impact of different time intervals. 5 of the 9 support our conclusion [14-18], 3 of the remaining 4 report contradictory results [19-22]. Benacerraf et al. [21] reported that there is no impact on the accuracy of the weight estimation caused by the time between investigation and delivery. The estimations were taken no more than 7 days before delivery and therefore cannot be compared to the results of our own study.

We can state that the accuracy of fetal weight estimation in our study is not influenced by the experience of the investigator. 6 studies paid attention to this question: 3 of them concluded that experience of the investigator has no impact [23-25] and 3 stated that experience has an impact on the preciseness of the estimation [26-28].

In our study the accuracy of fetal weight estimation was not influenced by the sex of the fetus. The fact that males have about 3\% more birth weight at term than females [29] was discussed together with the question of the accuracy of fetal weight estimation in only two further studies: Mills et al. [30], investigating preterm pregnancies (weeks 23-29), had the same result as we state here, and Honarvar et al. [31] reported a similar result investigating preterm pregnancies between weeks 24 and 34 . There was no statistically significant difference of the birth weight between males and females though females had about $46 \mathrm{~g}$ more average birth weight.

In our results we have seen no impact on the accuracy of fetal weight estimation when we compare lower gestational weeks with higher weeks $\left(<30 \mathrm{vs.} \geq 30^{\circ}\right)$. There are only two other studies analyzing the impact of gestational age on the accuracy of fetal weight estimation. Both conclude that gestational age has an impact on the estimation $[2,32]$.

Also we have seen no impact on the preciseness of the estimations when we compare the groups with lower $(<2,000)$ and higher fetal birth weight $(\geq 2,000 \mathrm{~g})$ using Hadlock II formula. To the best of our knowledge only Benacerraf et al. [21] published a study targeting the question if the accuracy of fetal weight estimation is influenced by the birth weight. As in our own study, Benacerraf reports no remarkable difference in the accuracy of fetal weight estimations in the different groups of birth weight $(<2,000 \mathrm{~g} 75 \%$ and $\geq 2,000 \mathrm{~g} 73.4 \%$ within $\pm 10 \%$ of ultrasound estimate). This study is remarkable because the design shows similar key characteristics as our own study: A large series of 1,301 women with single pregnancies, investigated in a defined time slot (1 week) before delivery in one institution was the base for the question if birth weight can be estimated with a certain safety and if the accuracy of the estimation is influenced by factors like amniotic fluid and the number of days between estimation and delivery.

A few studies state that different formulas for different classes of gestational weeks or different classes of fetal weight have differing accuracies or have the tendency to over/underestimate the actual weight. The concerning results are inhomogeneous and inconsistent $[2,10,12,19$, 33-37]. To our best knowledge it is not possible to draw a consistent conclusion on which formula is definitively the best in which subgroup.

In our study we had no impact of the BMI on the accuracy of the fetal weight estimation. Four other authors confirm this result [24, 38-40]. Furthermore, we cannot prove any influence of the amniotic fluid index on the accuracy of the estimations. The majority of the concerning studies state the same result $[18,30,38,39,41-46], 4$ authors draw a different conclusion [47-50].

The results of fetal weight estimation in our study are not influenced by the presentation of the fetus. Almost all available studies excluded different to cephalic presentations. Three studies support our conclusion [30, 47, 50]. Only the results of Chauhan et al. [51] came to the result that a cephalic presentation is linked to a higher accuracy of fetal weight estimation when compared with breech 
presentation ( 65.3 vs. $47.9 \%$ ) within the $\pm 10 \%$ range of the actual weight.

We cannot state that the location of the placenta influences the accuracy of fetal weight estimation. There are only 2 further studies dealing with this question. Both support our result $[18,38]$.

Finally we have to state that even very poor imaging conditions caused by high maternal BMI and low amniotic fluid does not influence the accuracy of fetal weight estimation in the investigated collective. The aim of answering this was the clinical experience that the babies of mothers with such restricted sight cannot be measured accurately because the traditional landmarks to set the caliper points cannot be visualized. There is no literature available that posed the same question.

The discussion of the literature concerning our results of accuracy of fetal weight estimation is influenced by the fact that most of the studies that we have taken into consideration do not state if they have eliminated factors that may have influenced their results such us multiples, fetuses with skeletal dysplasia, intrauterine growth restriction, etc. Furthermore, stratification for gestational age and fetal weight is rarely given. Finally, some authors report their results with the $\pm 10 \%$ range while others report the mean percentage error. Due to the facts mentioned above, complete comparability of different studies in the field of fetal weight estimation is rarely given. Being aware of this limitation we can state that our results concerning the accuracy of fetal weight estimation with 6 of the most widespread formulas are in accordance with previous reports in the literature.

\section{Conclusion}

The literature targeting different aspects (accuracy of formulas, influence factors) of sonographic fetal weight estimation is inhomogeneous concerning the reported results and interpretations.

To our knowledge this is the first study to investigate all important factors of influence on fetal weight estimation in a single group of singleton pregnancies at a single hospital. The accuracy of fetal weight estimation in this study was found to have the expected limitations (about $55-63 \%$ of the estimations within $\pm 10 \%$ range of the actual weight). Hadlock II formula gave us the best results. Even poor imaging conditions (high BMI and low AFI) have no impact on the precision of the estimation.

Fetal weight estimation is important to care for the pregnancy. It may influence the intenseness of monitoring and the time and mode of delivery. Pseudo-preciseness given by today's PACS should be carefully used, taking into consideration the limitations of the method and mainly the time interval between prenatal weight estimation and delivery.

\section{References}

1 Luke B: The changing pattern of multiple births in the United States: maternal and infant characteristics, 1973 and 1990. Obstet Gynecol 1994;84:101-106.

2 Mongelli M, Biswas A: Menstrual age-dependent systematic error in sonographic fetal weight estimation: a mathematical model. J Clin Ultrasound 2002;30:139-144.

3 Jouannic JM, Grange G, Goffinet F, Benachi A, Carbrol D: Validity of sonographic formulas for estimating fetal weight below 1,250 g: a series of 119 cases. Fetal Diagn Ther 2001;16:254-258.

4 Wong SF, Chan FY, Cincotta RB, Oats JJ, McIntyre HD: Sonographic estimation of fetal weight in macrosomic fetuses: diabetic versus non-diabetic pregnancies. Aust NZ J Obstet Gynaecol 2001;41:429-432.

5 Blickstein I: Growth aberration in multiple pregnancy. Obstet Gynecol Clin North Am 2005;32:39-54, viii.
6 Zador IE, Sokol RJ, Chik L: Interobserver variability. A source of error in obstetric ultrasound. J Ultrasound Med 1988;7:245249.

7 Snijders RJ, Nicolaides KH: Fetal biometry at 14-40 weeks' gestation. Ultrasound Obstet Gynecol 1994;4:34-48.

8 Hadlock FP, Harrist RB, Carpenter RJ, Deter RL, Park SK, Warsof SL, et al: Sonographic estimation of fetal weight. The value of femur length in addition to head and abdomen measurements. Radiology 1984;150:535540.

9 Hadlock FP, Harrist RB, Sharman RS, Deter RL, Park SK, Merz E, et al: Estimation of fetal weight with the use of head, body, and femur measurements - a prospective study. Am J Obstet Gynecol 1985;151:333-337.

10 Warsof SL, Gohari P, Berkowitz RL, Hobbins JC, Shepard MJ, Richards VA, et al: The estimation of fetal weight by computer-assisted analysis. Am J Obstet Gynecol 1977;128: 881-892.
11 Merz E, Lieser H, Schicketanz KH, Harle J: Intrauterine fetal weight assessment using ultrasound. A comparison of several weight assessment methods and development of a new formula for the determination of fetal weight (in German). Ultraschall Med 1988;9: 15-24.

12 Shepard MJ, Richards VA, Berkowitz RL, Warsof SL, Hobbins JC, Hadlock FP, et al: An evaluation of two equations for predicting fetal weight by ultrasound. Sonographic estimation of fetal weight: the value of femur length in addition to head and abdomen measurements. Am J Obstet Gynecol 1982; 142:47-54.

13 Moore TR, Cayle JE: The amniotic fluid index in normal human pregnancy. Am J Obstet Gynecol 1990;162:1168-1173.

14 Nzeh DA, Rimmer S, Moore WM, Hunt L: Prediction of birthweight by fetal ultrasound biometry. Br J Radiol 1992;65:987-989. 
15 Spinnato JA, Allen RD, Mendenhall HW: Birth weight prediction from remote ultrasound examination. Obstet Gynecol 1988; 71(6 Pt 1):893-898.

16 Mongelli M, Gardosi J: Gestation-adjusted projection of estimated fetal weight. Acta Obstet Gynecol Scand 1996;75:28-31.

17 Owen P, Donnet ML, Ogston SA, Christie AD, Howie PW, Patel NB: Standards for ultrasound fetal growth velocity. Br J Obstet Gynaecol 1996;103:60-69.

18 Scott F, Beeby P, Abbott J: Accuracy of estimated fetal weight below 1,000 g. Aust NZ J Obstet Gynaecol 1996;36:129-132.

19 Deter RL, Hadlock FP, Harrist RB, Carpenter RJ: Evaluation of three methods for obtaining fetal weight estimates using dynamic image ultrasound. J Clin Ultrasound 1981;9: 421-425.

20 Rossavik IK, Deter RL, Wasserstrum N: Mathematical modeling of fetal growth. V. Fetal weight changes at term. J Clin Ultrasound 1988;16:9-15.

21 Benacerraf BR, Gelman R, Frigoletto FD Jr: Sonographically estimated fetal weights: accuracy and limitation. Am J Obstet Gynecol 1988;159:1118-1121.

22 Kaaij MW, Struijk PC, Lotgering FK: Accuracy of sonographic estimates of fetal weight in very small infants. Ultrasound Obstet Gynecol 1999;13:99-102.

23 Valea FA, Watson WJ, Seeds JW: Accuracy of ultrasonic weight prediction in the fetus with preterm premature rupture of membranes. Obstet Gynecol 1990;75:183-185.

24 Field NT, Piper JM, Langer O: The effect of maternal obesity on the accuracy of fetal weight estimation. Obstet Gynecol 1995;86: 102-107.

25 Ben-Aroya Z, Segal D, Hadar A, Hallak M, Friger M, Katz M, et al: Effect of ob/gyn residents' fatigue and training level on the accuracy of fetal weight estimation. Fetal Diagn Ther 2002;17:177-181.

26 Hellmeyer L, Meyer-Wittkopf M, Ziegler A, Ballast A, Sierra F, Schmidt S: Comparison of sonographic weight estimation to actual birth weight: a retrospective analysis (in German). Ultraschall Med 2001;22:167-171.

27 Baum JD, Gussman D, Wirth JC 3rd: Clinical and patient estimation of fetal weight vs. ultrasound estimation. J Reprod Med 2002;47: 194-198.
28 Predanic M, Cho A, Ingrid F, Pellettieri J: Ultrasonographic estimation of fetal weight acquiring accuracy in residency. J Ultrasound Med 2002;21:495-500.

29 Davis RO, Cutter GR, Goldenberg RL, Hoffman HJ, Cliver SP, Brumfield CG: Fetal biparietal diameter, head circumference, abdominal circumference and femur length. A comparison by race and sex. J Reprod Med 1993;38:201-206.

30 Mills MD, Nageotte MP, Elliott JP, Crade M, Dorchester W: Reliability of ultrasonographic formulary in the prediction of fetal weight and survival of very-low-birth-weight infants. Am J Obstet Gynecol 1990;163(5 Pt 1):1568-1574.

31 Honarvar M, Allahyari M, Dehbashi S: A simple estimated fetal weight equation for fetuses between 24 and 34 weeks of gestation. Int J Gynaecol Obstet 1999;67:67-74.

32 Pressman EK, Bienstock JL, Blakemore KJ Martin SA, Callan NA: Prediction of birth weight by ultrasound in the third trimester. Obstet Gynecol 2000;95:502-506.

33 Chuang L, Hwang JY, Chang CH, Yu CH, Chang FM: Ultrasound estimation of fetal weight with the use of computerized artificial neural network model. Ultrasound Med Biol 2002;28:991-996.

34 Smith GC, Smith MF, McNay MB, Fleming JE: The relation between fetal abdominal circumference and birthweight: findings in 3512 pregnancies. Br J Obstet Gynaecol 1997; 104:186-190.

35 Dudley NJ: Selection of appropriate ultrasound methods for the estimation of fetal weight. Br J Radiol 1995;68:385-388.

36 Ferrero A, Maggi E, Giancotti A, Torcia F, Pachi A: Regression formula for estimation of fetal weight with use of abdominal circumference and femur length: a prospective study. J Ultrasound Med 1994;13:823-833.

37 Hill LM, Breckle R, Wolfgram KR, O’Brien PC: Evaluation of three methods for estimating fetal weight. J Clin Ultrasound 1986;14: 171-178.

38 Shamley KT, Landon MB: Accuracy and modifying factors for ultrasonographic determination of fetal weight at term. Obstet Gynecol 1994;84:926-930.

39 Blann DW, Prien SD: Estimation of fetal weight before and after amniotomy in the laboring gravid woman. Am J Obstet Gynecol 2000;182:1117-1120.

40 Farrell T, Holmes R, Stone P: The effect of body mass index on three methods of fetal weight estimation. BJOG 2002;109:651-657.
41 Patterson RM: Estimation of fetal weight during labor. Obstet Gynecol 1985;65:330332.

42 Bottoms SF, Welch RA, Zador IE, Sokol RJ: Clinical interpretation of ultrasound measurements in preterm pregnancies with premature rupture of the membranes. Obstet Gynecol 1987;69(3 Pt 1):358-362.

43 Townsend RR, Filly RA, Callen PW, Laros RK: Factors affecting prenatal sonographic estimation of weight in extremely low birthweight infants. J Ultrasound Med 1988;7: 183-187.

44 Medchill MT, Peterson CM, Kreinick C, Garbaciak J: Prediction of estimated fetal weight in extremely low birth weight neonates (500-1,000 g). Obstet Gynecol 1991;78: 286-290.

45 Toohey JS, Lewis DF, Harding JA, Crade M, Asrat T, Major CA, et al: Does amniotic fluid index affect the accuracy of estimated fetal weight in preterm premature rupture of membranes? Am J Obstet Gynecol 1991; 165(4 Pt 1):1060-1062.

46 Meyer WJ, Font GE, Gauthier DW, Myles TD, Bieniarz A, Rodriguez A: Effect of amniotic fluid volume on ultrasonic fetal weight estimation. J Ultrasound Med 1995;14:193197.

47 O'Keeffe DF, Garite TJ, Elliott JP, Burns PE: The accuracy of estimated gestational age based on ultrasound measurement of biparietal diameter in preterm premature rupture of the membranes. Am J Obstet Gynecol 1985;151:309-312.

48 Divon MY, Chamberlain PF, Sipos L, Platt LD: Underestimation of fetal weight in premature rupture of membranes. J Ultrasound Med 1984;3:529-531.

49 Barnhard Y, Bar-Hava I, Divon MY: Accuracy of intrapartum estimates of fetal weight. Effect of oligohydramnios. J Reprod Med 1996;41:907-910.

50 Edwards A, Goff J, Baker L: Accuracy and modifying factors of the sonographic estimation of fetal weight in a high-risk population. Aust NZ J Obstet Gynaecol 2001;41: 187-190.

51 Chauhan SP, Magann EF, Naef RW 3rd, Martin JN Jr, Morrison JC: Sonographic assessment of birth weight among breech presentations. Ultrasound Obstet Gynecol 1995;6: 54-57. 